\title{
Understanding the relationship between self-esteem and current grade point average of college undergraduates
}

Jennifer L. Wiles

West Virginia University

Follow this and additional works at: https://researchrepository.wvu.edu/etd

\section{Recommended Citation}

Wiles, Jennifer L., "Understanding the relationship between self-esteem and current grade point average of college undergraduates" (2004). Graduate Theses, Dissertations, and Problem Reports. 732.

https://researchrepository.wvu.edu/etd/732

This Thesis is protected by copyright and/or related rights. It has been brought to you by the The Research Repository @ WVU with permission from the rights-holder(s). You are free to use this Thesis in any way that is permitted by the copyright and related rights legislation that applies to your use. For other uses you must obtain permission from the rights-holder(s) directly, unless additional rights are indicated by a Creative Commons license in the record and/ or on the work itself. This Thesis has been accepted for inclusion in WVU Graduate Theses, Dissertations, and Problem Reports collection by an authorized administrator of The Research Repository @ WVU. For more information, please contact researchrepository@mail.wvu.edu. 
Understanding the Relationship between Self-Esteem and Current Grade Point Average of College Undergraduates

\author{
Jennifer L.Wiles
}

Thesis submitted to the College of Human Resources and Education at West Virginia University in partial fulfillment of the requirements

for the degree of

\author{
Master of Arts \\ in \\ Educational Psychology \\ Larry Stead, Ed.D., Chair \\ Richard Walls, Ph.D., \\ Ernest Goeres, Ph.D.
}

Department of Educational Psychology

\author{
Morgantown, West Virginia \\ 2004
}

Keywords: Grade Point Average, Self-Esteem

Copyright 2004 Jennifer L. Wiles 


\section{ABSTRACT \\ Understanding the Relationship between Self-Esteem and Current Grade Point Average of College Undergraduates}

\section{Jennifer L. Wiles}

The author investigated the relationship between undergraduates' self-esteem (current and retrospective) and their current grade point average. Specifically, the author investigated the relationship between students' self-esteem (fifth grade, eleventh grade, and undergraduate) and their current undergraduate grade point average. A sample of 95 college students from West Virginia University completed the Rosenberg Self-Esteem Scale. The author assessed the relationship by performing six correlations and three reliability estimates for each self-esteem survey. The results showed a strong correlation between fifth grade self-esteem and current grade point average, but there was no significant correlation at the eleventh grade and undergraduate level. Also, the author found significant correlations between each of the total self-esteem scores. Therefore, there was a significant correlation between the two variables at the fifth grade level, but the correlation is not significant as the student ages (during eleventh grade and undergraduate). 


\section{Table of Contents}

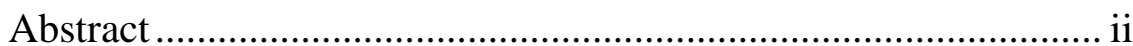

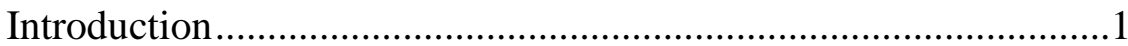

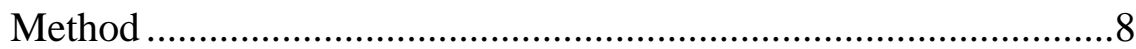

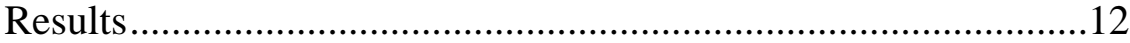

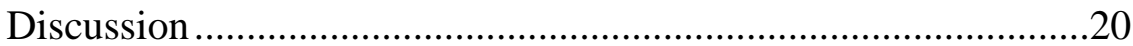

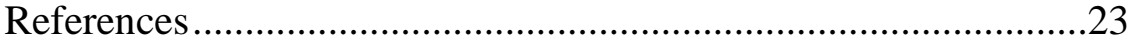

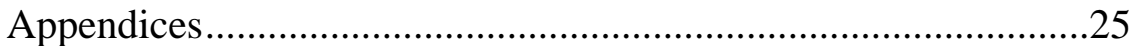

(A) Fifth Grade Self-Esteem Scale

(B) Eleventh Grade Self-Esteem Scale

(C) Undergraduate Self-Esteem Scale

(D) Demographics Questionnaire

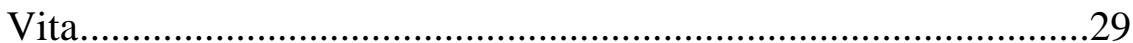




\section{Introduction}

Extensive research has been conducted over the past few decades to emphasize the importance of self-esteem and its relationship to academic achievement. Many researchers have utilized different instruments, aspects of achievement, and goals, but the findings are still quite inconclusive. Although a great deal of research directly relates self-esteem and academic achievement to at least a moderate degree, there are still findings that suggest that no correlation exists between the two variables. The topic is very important to students, teachers, and parents of all children who may want to find a definite link between the two variables.

According to Coopersmith (1986), self-esteem is "the evaluation a person makes and maintains with regard to him or herself.” While researching self-esteem, it seems relevant to look at the impact it may have on academic achievement or the impact that one’s academic achievement may have on one’s self-esteem. As Kinney and Miller (1988) have discussed, perhaps those students who have higher self-esteem also have achieved more academically. However, this relationship may be due to motivation or other such extraneous variables. Likewise, students who have higher academic achievement may have higher self-esteem scores due to other extraneous variables. This “circular relationship” should be studied to explore a correlation between the two. Researchers may not be able to rule out all extraneous variables, but some may find a certain link between the two that can be helpful to future educators and students. If higher self-esteem is highly correlated with greater academic achievement, educators can use this information to help younger students develop a higher self-esteem, which could 
ultimately lead to an increase of academic achievement. Also, if having higher academic achievement is highly correlated with higher self-esteem, educators can use this information to help younger students focus more on academic achievement to potentially develop a higher self-esteem.

Perhaps this lack of knowledge about the relationship between the two variables could be detrimental to the students' future academic achievement and their self-esteem. As students progress through the educational years, they begin to understand the concept of academic achievement. When one takes a test, he/she earns a grade that exemplifies the academic achievement for that content. This fact stresses the importance of learning the material well enough to achieve a good grade, such as getting an " $\mathrm{A}$ ” on a math test. However, if a student does poorly, he/she may earn a lower grade, such as getting an "F" on a math test. Whether or not this directly affects his/her self-esteem could be detrimental to both his/her future self-esteem and future academic achievement. The different levels of one’s self-esteem could directly affect his/her academic achievement. For example, will a student with low self-esteem try to earn the higher grade or simply be satisfied with the lower grade? Also, will higher self-esteem motivate a student to work harder to earn the higher grade? There is no relevant way to find a causal relationship between the two variables. Researchers can only explore the correlation between the two that may direct future research in this area.

The present study will explore the relationship between current grade point average and one's self-esteem at three different points in life. The researcher wants to find changes in self-esteem during these three points in life and their relationship to the 
participants' current grade point average. Specifically, is there a correlation between self-esteem and current grade point average (fifth grade to current grade point average, eleventh grade to current grade point average, and/or undergraduate to current grade point average)? Data suggests that there are relationships between the two variables at some points in life but not others. Researchers have spent a vast amount of time studying the relationship between self-esteem and academic achievement. Many have studied school-aged children, adolescents, and even undergraduate students, but the findings are still inconclusive regarding the relationship between the two variables.

As Frerichs (1971) discussed, there is evidence that having a positive self-image may lead to greater school success. While looking at school-aged children, Bledsoe (1964) also found a significantly positive correlation between self-esteem and academic achievement among fourth-grade and sixth-grade boys. Specifically, those children who had a higher grade point average scored higher on the self-esteem inventory than those who had a lower grade point average. Wiggins, Schatz, and West (1994) also looked at the correlation between the two variables of students from grades 4 through 12 . They studied students in October and again in May and found that students whose self-esteem score increased at least 15 points from October to May significantly increased their grade point averages the following year. Maruyama, Rubin, and Kingsbury (1981) also researched the topic of children between the ages of 4 and 15 . Within the domain of selfconcept, they specifically looked at self-esteem and how it related to school-aged children's academic achievement. They found that neither achievement nor self-esteem exerted, "any 'causal' influence on the other." They concluded that the reason for the 
absence of a relationship between the two variables is that the subjects of their study have reached ages at which both variables seem to be stable. According to the authors, causal relations may occur only during the first years of school. They further state that there may be reciprocal relations, but those relationships decline as children increase with age and achievement (and perhaps self-esteem) becomes more stable. Therefore, there is still inconclusive data regarding the relationship of the two variables during the earlier years of one’s life.

Researchers have also looked at the relationship of the two variables among high school students. In an investigation of high school seniors, researchers have found that educational accomplishments seem to become less important for self-esteem during the late teens and early twenties (O’Malley \& Bachman, 1979). They discuss that during the high school years and the years that follow, people experience far more situations that tend to relate to self-esteem than academic achievement. The authors believe that academic achievements become less dominant in shaping self-esteem later in life.

There have also been many investigations done on college students to examine the relationship between grade point average and self-esteem. Researchers suggest a commonly reported relationship between the two variables among children and adolescents (Demo \& Savin-Williams 1983; Rosenberg \& Pearlin, 1978). However, other investigations have suggested educational success becomes less influential in molding self-esteem during late high school and the years that follow (Bachman \& O’Malley, 1977; O’Malley \& Bachman, 1979). Also, Purkey (1970) suggests a 
“circular” process where academic achievement helps increase self-esteem, and higher self-esteem also helps to increase academic achievement. Is the relationship between the two variables significantly less correlated after high school?

In an investigation done by Demo and Parker (2001), the authors found no association between academic achievement and self-esteem overall. They suggested that self-esteem did not influence academic achievement. However, the results showed that academic achievement had a somewhat conditional effect on self-esteem. Specifically, they found that when white females have low self-esteem, their self-esteem seems to be correlated with their academic achievement. These findings did not support the original research, which concluded that academic achievement, in relation to self-esteem, declines in significance following high school years. The authors suggest that for white females, academic achievement exerts a conditional influence on self-esteem. Overall, they found no correlation between academic achievement and self-esteem. They suggest that perhaps academic achievement does not affect self-esteem during the transition to adulthood. Also, Cokey (2002) looked at the relationship between self-esteem and grade point average among European-American undergraduate students. He, too, found no significant correlation between self-esteem and grade point average.

In another investigation attempting to find a correlation between the two variables, Tsai (2001) and others have found results that tend to differ from previous research. While studying Chinese-American college students, the author found that grade point average was a significant predictor of self-esteem. Also, the results showed a positive correlation between self-esteem and grade point average among the students. 
Research has also been conducted by Woo and Frank (2000) that examined the relationship between the two variables with United States college students. Their results showed a significant positive correlation between self-esteem and overall grade point average as well. In another study done by Okun and Fournet (1993), they looked at the self-verification theory. According to this theory, students with high self-esteem are apt to have good academic performance, and students with low self-esteem tend to have lower academic performance. The authors also looked at 281 undergraduates to find a relationship between the two variables. They, too, found a positive relationship between self-esteem and grade point average among undergraduate students.

These inconsistent findings result in a lack of understanding the relationship between grade point average and self-esteem, especially among college undergraduates. Although a small fraction of researchers disagree, many find a relationship between the two variables during childhood and adolescence. However, the relationship between the two variables during the transition to adulthood, or after, is unclear.

\section{The Study}

The research and null hypotheses for this study are stated below. The independent variable investigated was cumulative grade point average. The dependent variable of this study was self-esteem. This dependent variable had three levels: selfesteem in fifth grade, self-esteem in eleventh grade, and self-esteem now (during undergraduate studies). 


\section{Hypotheses}

$\underline{\mathbf{H}_{i}:} \quad$ There will be a significant correlation between self-esteem and grade point average (fifth grade to current grade point average, eleventh grade to current grade point average, and/or undergraduate to current grade point average). Additionally, there will be a significant correlation between the three total self-esteem scores at the three different periods of the student's life (fifth grade, eleventh grade, and undergraduate).

$\underline{\mathbf{H}_{\mathbf{0}}} \mathbf{-} \quad$ There will be no significant correlation between self-esteem and grade point average (fifth grade to current grade point average, eleventh grade to current grade point average, and/or undergraduate to current grade point average). Additionally, there will be no significant correlation between the three total self-esteem scores at the three different periods of the student's life (fifth grade, eleventh grade, and undergraduate). 


\section{Method}

\section{$\underline{\text { Participants }}$}

The participants for the current study were undergraduate students at West Virginia University. The students had to be at least juniors and enrolled in the education program. Specifically, they needed to have completed at least 59 credit hours. The students in this population encompassed a mixture of ability and achievement levels based on the fact that they were a cross-section of students in the education program. The specific sample used in this study consisted of one specific undergraduate education course, which included five different sections. There were 95 participants involved in the present investigation.

\section{Design}

The researcher used the correlational design to explore the relationships between and among the variables with a retrospective administration. There were 2 sets of correlations, with 3 correlations in each set. The first set of correlations was done on self-esteem across time. The second set was done on cumulative grade point average with self-esteem across time. The following six correlations were conducted on the variables:

1. A correlation between $5^{\text {th }}$ grade self-esteem and $11^{\text {th }}$ grade self-esteem

2. A correlation between $11^{\text {th }}$ grade self-esteem and current (undergraduate) self-esteem

3. A correlation between $5^{\text {th }}$ grade self-esteem and undergraduate self-esteem 
4. A correlation between $5^{\text {th }}$ grade self-esteem and cumulative grade point average

5. A correlation between $11^{\text {th }}$ grade self-esteem and cumulative grade point average

6. A correlation between current (undergraduate) self-esteem and cumulative grade point average

The researcher also conducted three reliability estimates for each point in time (selfesteem in fifth grade, eleventh grade, and current undergraduate self-esteem). The dependent variable was the total score on the Rosenberg Self-Esteem Scale (RSES). The independent variable was the cumulative grade point average.

\section{Procedure}

Each participant was given three copies of the RSES (one to complete for fifth grade, one for eleventh grade, and one for current self-esteem). They were also given a page with demographic questions to complete. The entire survey was completed in one sitting by each of the students. The complete survey was counterbalanced to insure an equitable number of responses to the different questions throughout the survey. For example, each student filled out a different page of the survey at different times. The following is the format that was used for counterbalancing the survey:

Student \# : $\quad$ Page numbers in order to be filled out:

$\begin{array}{llll}1 & 1 & 2 & 3 \\ 2 & 2 & 3 & 1 \\ 3 & 3 & 1 & 2 \\ 4 & 1 & 3 & 2 \\ 5 & 2 & 1 & 3 \\ 6 & 3 & 2 & 1\end{array}$


After this sequence was completed, the sequence was then repeated until all of the surveys are counterbalanced in the same order. To view the complete survey, see Appendices A - D.

\section{Instrument}

The researcher used the Rosenberg Self-Esteem Scale to measure the participants' current self-esteem and a retrospective administration to look at self-esteem from fifth grade and eleventh grade as well. The measure is a ten item scale that is used to measure self-esteem of participants ages 18 years or older. The range of scores is 10 to 40, with ten being the minimum and forty being the maximum score. The student chose the best answer dealing with his/her general feelings about himself/herself. The answers ranged from strongly agree to strongly disagree, with strongly disagree having the value of 1 , and strongly agree having the value of 4 . Also, numbers $3,5,8,9$, and 10 are reverse scored on the self-esteem scale. The scoring for these items needed to be reversed so that, in each case, the scores ranged from lower to higher levels of selfesteem. The reliability for this scale are generally high: the test-retest correlations are typically in the range of .82 to .88 , and Cronbach’s alpha for various samples are in the range of .77 to .88 (Rosenberg, 1965).

\section{Data Collection}

The entire survey was given prior to the start of each teacher's lecture. The teacher introduced the investigator and asked each student for his/her participation. The investigator then explained the study and encouraged the students to fill out the survey only if the student felt comfortable with it. The investigator gave each participant 
(student) a survey and explained that they were simply to follow the directions provided on the survey. The participants individually completed the survey, having approximately 10 to 20 minutes each to complete it. The investigator collected all of the surveys and ensured the students that each survey would be kept completely anonymous. 


\section{Results}

The results of this study are presented to answer the research hypotheses. The intent of the investigation was to understand the relationship between self-esteem and current grade point average for college undergraduates. Thus, the relationship (correlation) between an individual's current grade point average and current, as well as retrospective, self-esteem was considered relevant. Also, the relationship between an individual's self-esteem during fifth grade, eleventh grade, and undergraduate was considered relevant.

\section{Hypothesis 1}

There will be a significant correlation between self-esteem and grade point average (fifth grade to current grade point average, eleventh grade to current grade point average, and/or undergraduate to current grade point average). To address this hypothesis, three correlation coefficients were computed. They were zero-order Pearson Product-Moment Correlations. The correlation between fifth grade self-esteem and current grade point average was $r=0.266, p<0.01$. The correlation between eleventh grade self-esteem and current grade point average was $r=0.076, p<0.01$. The correlation between undergraduate self-esteem and current grade point average was $r=$ $0.028, p<0.01$. These findings with the number of students responding are summarized in Table 1. These findings tend to partially support the hypothesis that there would be a correlation between self-esteem and current grade point average. Specifically, there was a strong correlation between the fifth grade self-esteem and current grade point average, 
but the correlation is not significant as the individuals get older. This overall finding is illustrated in Figure 1. 


\section{Table 1}

Correlation Analyses for Hypothesis 1.

\begin{tabular}{lcll}
\hline Self-Esteem & $\mathrm{N}$ & $\begin{array}{l}\text { GPA } \\
\text { Correlation }\end{array}$ & $\begin{array}{l}\text { Significance } \\
\text { Level }\end{array}$ \\
\hline Fifth Grade & 94 & $r=0.266$ & $p<.01$ \\
Eleventh Grade & 95 & $r=0.076$ & NS** \\
Undergraduate & 95 & $r=-0.028$ & NS** \\
\hline
\end{tabular}

$* *$ NS $=$ Not Significant at $p<.05$ 
Figure 1. Hypothesis 1 correlations of retrospective and current administration of selfesteem and grade point average.

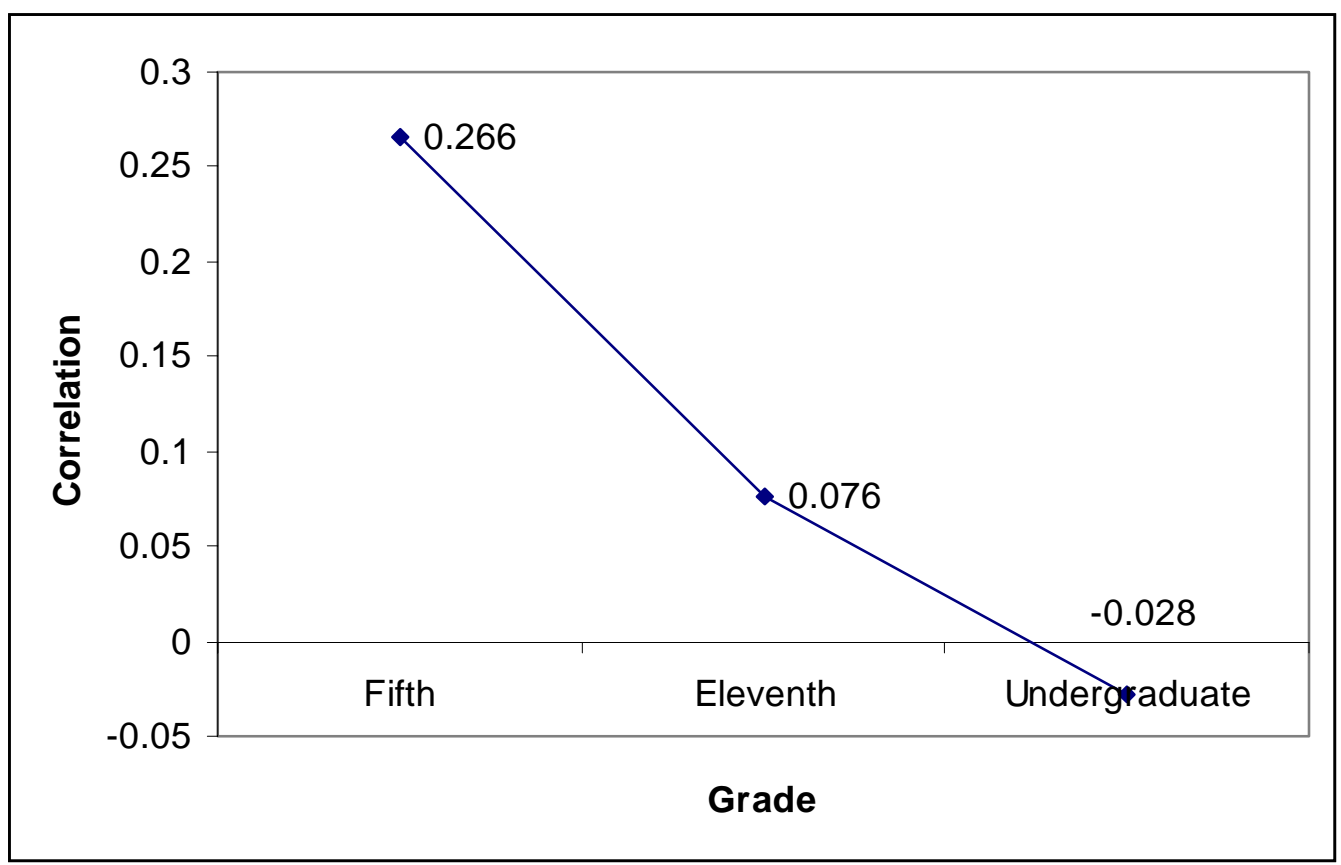




\section{Hypothesis 2}

There will be a significant correlation between the three total self-esteem scores at the three different periods of the student's life (fifth grade, eleventh grade, and undergraduate). To address this hypothesis, three correlation coefficients were computed. They were also zero-order Pearson Product-Moment Correlations. The correlation between fifth grade self-esteem and eleventh grade self-esteem was $r=0.490, p<.01$. The correlation between eleventh grade self-esteem and undergraduate self-esteem was $r=0.560, p<.01$. The correlation between fifth grade self-esteem and undergraduate self-esteem was $r=0.460, p<.01$. These findings with the number of students responding are summarized in Table 2. These findings support the hypothesis that there would be significant correlation between the three retrospective self-esteem scores. Specifically, there were significant correlations between each of the three self-esteem scores (fifth grade, eleventh grade, and undergraduate). This overall finding is illustrated in Figure 2. 
Table 2

Correlation Analyses for Hypothesis 2.

\begin{tabular}{lcll}
\hline $\begin{array}{l}\text { Self-Esteem } \\
\text { Correlation }\end{array}$ & $\mathrm{N}$ & $\begin{array}{l}\text { Correlation } \\
\text { Coefficient }\end{array}$ & $\begin{array}{l}\text { Significance } \\
\text { Level }\end{array}$ \\
\hline $\begin{array}{l}\text { Fifth Grade \& } \\
\text { Eleventh Grade }\end{array}$ & 95 & $r=0.490$ & $p<.01$ \\
$\begin{array}{l}\text { Eleventh Grade \& } \\
\text { Undergraduate }\end{array}$ & 95 & $r=0.560$ & $p<.01$ \\
$\begin{array}{l}\text { Fifth Grade \& } \\
\text { Undergraduate }\end{array}$ & 95 & $r=0.460$ & $p<.01$ \\
\hline
\end{tabular}


Figure 2. Hypothesis 2 correlations between retrospective and current administration of self-esteem in fifth grade, eleventh grade, and undergraduate.

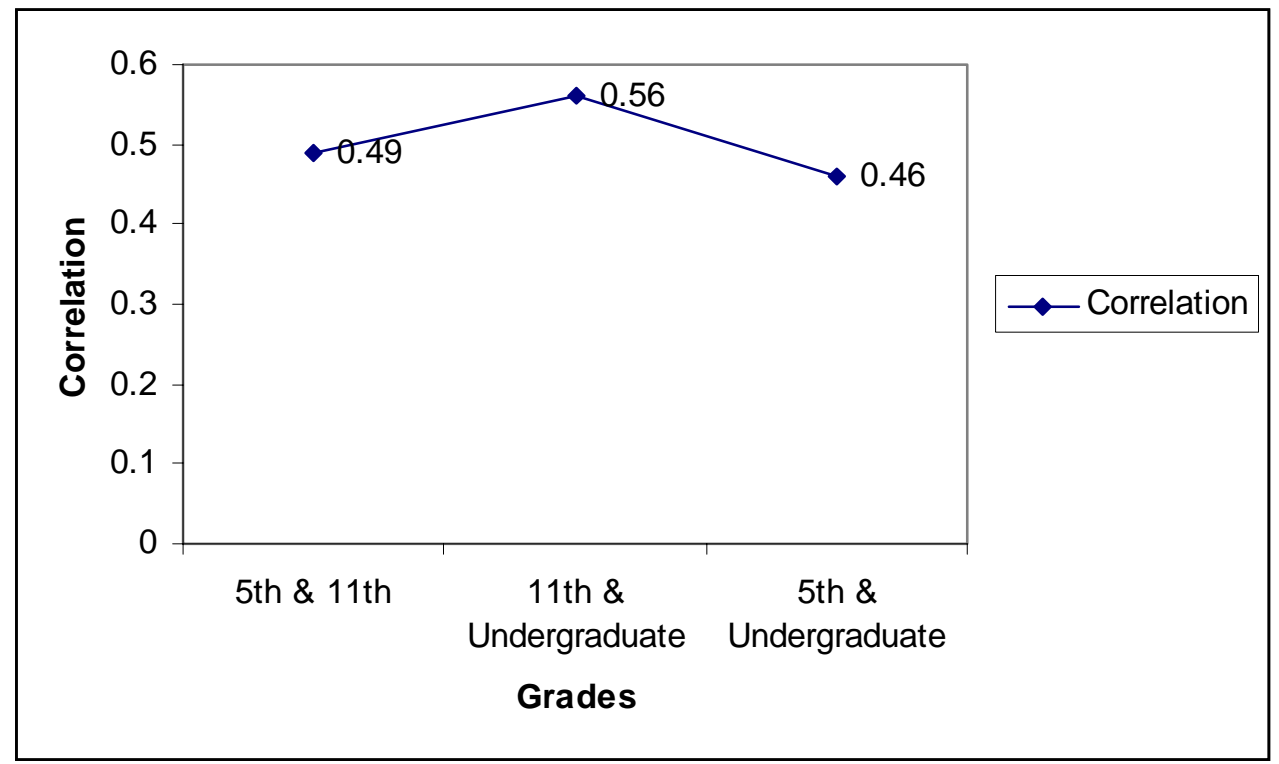


The results showed that there was a significant correlation at the 0.01 level between self-esteem in fifth grade and self-esteem in eleventh grade. There was also a significant correlation at the 0.01 level between self-esteem in eleventh grade and selfesteem during undergraduate studies. Also, at the 0.01 level there was a significant correlation between self-esteem during undergraduate studies and self-esteem during fifth grade. Lastly, there was a significant correlation at the 0.01 level between self-esteem in fifth grade and current cumulative undergraduate grade point average. There was no significant correlation between cumulative grade point average and self-esteem in eleventh grade. Also, there was not a significant correlation between cumulative grade point average and self-esteem during undergraduate studies.

When the response scale for a survey is greater than two points, the coefficient alpha is commonly used to document the level of internal consistency reliability. This is to show that all of the items are measuring the same context as the others. Coefficient alpha was calculated for each administration of the RSES. The alpha coefficient for reliability during fifth grade was 0.91 . The alpha coefficient during eleventh grade was 0.92. The alpha coefficient during undergraduate was 0.91 . Therefore, the items within this scale were highly correlated with one another. This indicates high internal consistency and reliability for this population. 


\section{Discussion}

The current study investigated the relationships between cumulative undergraduate grade point average and self-esteem at three different periods of life. At the onset of the study, it was hypothesized that there would be at least one significant correlation between self-esteem and cumulative grade point average. It was also hypothesized that there would be significance in correlation between the three total selfesteem scores. The primary analyses were six different correlations among the three selfesteem tests and the self-esteem tests with cumulative grade point average. The independent variable was the cumulative grade point average, and the dependent variable was the total score on the RSES. The overall results showed a statistically significant positive correlation between self-esteem in fifth grade and in eleventh grade, between self-esteem in eleventh grade and in undergraduate, between self-esteem in fifth grade and in undergraduate, and between self-esteem in fifth grade and cumulative grade point average. However, there were no significant correlations between self-esteem in eleventh grade and current grade point average, or between self-esteem in undergraduate and current grade point average.

These results showed that the self-esteem of these students has not significantly changed between fifth grade, eleventh grade, and undergraduate studies. The total score on the RSES at each of these times is significantly correlated to each of the others. Also, the significant, positive correlation between self-esteem in fifth grade and cumulative grade point average supports earlier findings of a correlation between the two variables when studying children. Overall, previous researchers have found no correlation between 
academic achievement and self-esteem in participants in late high school (O’Malley \& Bachman, 1979). They suggest that perhaps academic achievement does not affect selfesteem during the transition to adulthood that occurs during high school. The current study also supports their findings. Although previous studies have illustrated mixed findings, the current investigation found no significant correlation between the two variables at the undergraduate level. The results of this study could be useful to students, teachers, and parents who want to find a link or relationship between the given variables.

One possible explanation for the absence of a significant correlation between selfesteem in eleventh grade and current grade point average or between undergraduate selfesteem and current grade point average is that achievement becomes more stable in high school and the years that follow. Therefore, the strong relationship between the two variables may start to diminish. Perhaps academic achievement does not affect selfesteem during the transition to adulthood.

Many confounding variables could have influenced this study. One major limitation that may have altered the total RSES scores was the retrospective administration of the surveys. Students may have had difficulty remembering their selfesteem during earlier stages of life. Another limitation is that self-esteem data in the present study are limited to a single wave of self-report measures. Perhaps the results would have been different if other classes, majors, or universities had been studied as well. Additionally, investigator personality could have influenced the results of the survey. 
In the future, this study could be expanded to encompass different views about the survey that was distributed to the participants. One area of focus could be the students' attitudes or beliefs about the relationship between the two variables. If a student believes that one variable causes or is significantly correlated to the other, a positive relationship could possibly be formed. Conversely, if the students do not think that one variable causes or is significantly correlated to the other, a negative relationship could be formed. Also, this view may diminish the chances of a possible relationship between the two variables. A second area of concentration for future research could be investigating the relationship between other variables along with the two current variables. For example, researchers could investigate the possible relationships of students' motivation, need for achievement (perfectionism), personality, or other demographic variables as well. This study could be further enlarged by also looking beyond correlations with other variables. Researchers may be able to find causal relationships that affect the currently investigated variables and their relationships.

The results of this study concur with what the researcher expected to find, at least one significant correlation between the variables. The study indicated that there is a significant correlation between self-esteem and grade point average in younger students. Though the relationship may diminish as the students age, the researcher strongly believes that there is a correlation between the two variables at one point that could influence the variables and/or other variables. 


\section{REFERENCES}

Bachman, J. G., \& O’Malley, P. M. (1977). Self-esteem in young men: A longitudinal analysis of the impact of educational and occupational attainment. Journal of Personality and Social Psychology, 35, 365-380.

Blatt, S. J. (1995). The destructiveness of perfectionism. American Psychologist, 50 (12), 1003-1020.

Bledsoe, J. C. (1964). Self concepts of children and their intelligence, achievement, interests, and anxiety. Journal of Individual Psychology, 20, 55-58.

Cokley, K. O. (2002). Ethnicity, gender, and academic self-concept: A preliminary examination of academic disidentification and implications for psychologists. Cultural Diversity and Ethnic Minority Psychology, 8, 378-388.

Coopersmith, S. (1986). Self-esteem inventories $\left(2^{\text {nd }}\right.$ ed.). Palo, Alto, California: Consulting Psychologists Press.

Demo, D. H., \& Parker, K. D. (2001). Academic achievement and self-esteem among black and white college students. Journal of Social Psychology, 127, 345-355.

Demo, D. H., \& Savin-Williams, R. C. (1983). Early adolescent self-esteem as a function of social class: Rosenberg and Pearlin revisited. American Journal of Sociology, 88, 763-774.

Frerichs, A. H. (1971). Relationship of self-esteem of the disadvantaged to school success. Journal of Negro Education, 40, 117-120.

Kinney, P., \& Miller, M. J. (1988). The relationship between self-esteem and academic achievement. College Student Journal, 22, 358-362.

LoCicero, K. A., Ashby, J. S., \& Kern, R. M. (2002). Multidimensional perfectionism and lifestyle approaches in middle school students. Journal of Individual Psychology, 56, 4-14.

Maruyama, G., Rubin, R. A., \& Kingsbury, G. G. (1981). Self-esteem and educational achievement: Independent constructs with a common cause. Journal of Personality and Social Psychology, 40, 962-975.

Okun, M. A., \& Fournet, L. M. (1993). Academic self-esteem and perceived validity of grades: A test of self-verification theory. Contemporary Educational Psychology, 18, 414-426. 
O’Malley, P. M., \& Bachman, J. G. (1979). Self-esteem and education: Sex and cohort comparisons among high school seniors. Journal of Personality and Social Psychology, 37, 1153-1159.

Purkey, W. W. (1970). Self-concept and school achievement. Englewood Cliffs, N.J.: Prentice-Hall.

Ray, J. J. (1975). A behavior inventory to measure motivation. Journal of Social Psychology, 95, 135-136.

Rosenberg, M. (1965). Society and adolescent self-image. Princeton, NJ: Princeton University Press.

Rosenberg, M., \& Pearling, L. (1978). Social class and self-esteem among children and adults. American Journal of Sociology, 84, 53-77.

Swann, W. B., JR., Griffin, J. J., Predmore, S. C., \& Gaines, B. (1987). The cognitiveaffective crossfire: When self-consistency confronts self-enhancement. Journal of Personality and Social Psychology, 52, 881-889

Tsai, J. L. (2001). Cultural predictors of self-esteem: A study of Chinese American female and male young adults. Cultural Diversity and Ethnic Minority Psychology, 7, 284-297.

Wiggins, J. D., Schatz, E. L., \& West, R. W. (1994). The relationship of self-esteem to grades, achievement scores, and other factors critical to school success. The School Counselor, 41, 238-244.

Woo, T. O., \& Frank, N. (2000). Academic performance and perceived validity of grades: An additional case for self-enhancement. Journal of Social Psychology, 140, 218-226. 


\section{Appendix A}

\section{FIFTH GRADE}

ROSENBERG SELF-ESTEEM SCALE (RSES)

BELOW IS A LIST OF STATEMENTS DEALING WITH YOUR GENERAL FEELINGS ABOUT YOURSELF. IF YOU STRONGLY AGREE, CIRCLE SA. IF

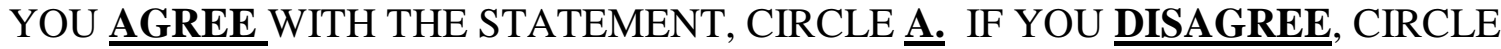
D. IF YOU STRONGLY DISAGREE, CIRCLE $\underline{\text { SD. }}$

THINK BACK TO WHEN YOU WERE IN FIFTH GRADE. TAKE A MOMENT TO THINK OF HOW YOU FELT. ALTHOUGH YOUR FEELINGS MAY BE DIFFERENT, PLEASE ANSWER THE QUESTIONS ACCORDING TO HOW YOU FELT THEN!!!

\begin{tabular}{|l|c|c|c|c|}
\hline & $\begin{array}{l}\text { 1. } \\
\text { STRONGLY } \\
\text { AGREE }\end{array}$ & AGREE & DISAGREE & $\begin{array}{l}\text { 4. } \\
\text { STRONGLY } \\
\text { DISAGREE }\end{array}$ \\
\hline $\begin{array}{l}\text { 1. I feel that I'm a } \\
\text { person of worth, at } \\
\text { least on an equal } \\
\text { plane with others. }\end{array}$ & SA & A & D & SD \\
\hline $\begin{array}{l}\text { 2. I feel that I have } \\
\text { a number of good } \\
\text { qualities. }\end{array}$ & SA & A & D & SD \\
\hline $\begin{array}{l}\text { 3. All in all, I am } \\
\text { inclined to feel that } \\
\text { I am a failure. }\end{array}$ & SA & A & D & SD \\
\hline $\begin{array}{l}\text { 4. I am able to do } \\
\text { things as well as } \\
\text { most other people. }\end{array}$ & SA & A & D & SD \\
\hline $\begin{array}{l}\text { 5. I feel I do not } \\
\text { have much to be } \\
\text { proud of. }\end{array}$ & SA & A & D & SD \\
\hline $\begin{array}{l}\text { 6. I take a positive } \\
\text { attitude toward } \\
\text { myself. }\end{array}$ & SA & A & D & SD \\
\hline $\begin{array}{l}\text { 7. On the whole, I } \\
\text { am satisfied with } \\
\text { myself. }\end{array}$ & SA & A & D & SD \\
\hline $\begin{array}{l}\text { 8. I wish I could } \\
\text { have more respect } \\
\text { for myself. }\end{array}$ & SA & A & D & SD \\
\hline $\begin{array}{l}\text { 9. I certainly feel } \\
\text { useless at times. }\end{array}$ & SA & A & D & SD \\
\hline $\begin{array}{l}\text { 10. At times I } \\
\text { think I am no good } \\
\text { at all. }\end{array}$ & SA & A & D & SD \\
\hline
\end{tabular}




\section{Appendix B}

\section{ELEVENTH GRADE}

ROSENBERG SELF-ESTEEM SCALE (RSES)

BELOW IS A LIST OF STATEMENTS DEALING WITH YOUR GENERAL FEELINGS ABOUT YOURSELF. IF YOU STRONGLY AGREE, CIRCLE SA. IF YOU AGREE WITH THE STATEMENT, CIRCLE A. IF YOU DISAGREE, CIRCLE D. IF YOU STRONGLY DISAGREE, CIRCLE SD.

THINK BACK TO WHEN YOU WERE IN ELEVENTH GRADE. TAKE A MOMENT TO THINK OF HOW YOU FELT. ALTHOUGH YOUR FEELINGS MAY BE DIFFERENT, PLEASE ANSWER THE QUESTIONS ACCORDING TO HOW YOU FELT THEN!!!

\begin{tabular}{|c|c|c|c|c|}
\hline & $\begin{array}{l}1 . \\
\text { STRONGLY } \\
\text { AGREE }\end{array}$ & $\begin{array}{l}2 . \\
\text { AGREE }\end{array}$ & $\begin{array}{l}3 . \\
\text { DISAGREE }\end{array}$ & $\begin{array}{l}4 . \\
\text { STRONGLY } \\
\text { DISAGREE }\end{array}$ \\
\hline $\begin{array}{l}\text { 1. I feel that I'm a } \\
\text { person of worth, at } \\
\text { least on an equal } \\
\text { plane with others. }\end{array}$ & SA & A & $\mathrm{D}$ & SD \\
\hline $\begin{array}{l}\text { 2. I feel that I have } \\
\text { a number of good } \\
\text { qualities. }\end{array}$ & SA & A & $\mathrm{D}$ & SD \\
\hline $\begin{array}{l}\text { 3. All in all, I am } \\
\text { inclined to feel that } \\
\text { I am a failure. }\end{array}$ & SA & A & $\mathrm{D}$ & SD \\
\hline $\begin{array}{l}\text { 4. I am able to do } \\
\text { things as well as } \\
\text { most other people. }\end{array}$ & SA & A & $\mathrm{D}$ & SD \\
\hline $\begin{array}{l}\text { 5. I feel I do not } \\
\text { have much to be } \\
\text { proud of. }\end{array}$ & SA & A & $\mathrm{D}$ & SD \\
\hline $\begin{array}{l}6 . \text { I take a positive } \\
\text { attitude toward } \\
\text { myself. }\end{array}$ & SA & A & $\mathrm{D}$ & SD \\
\hline $\begin{array}{l}\text { 7. On the whole, I } \\
\text { am satisfied with } \\
\text { myself. }\end{array}$ & SA & A & D & SD \\
\hline $\begin{array}{l}\text { 8. I wish I could } \\
\text { have more respect } \\
\text { for myself. }\end{array}$ & SA & A & $\mathrm{D}$ & SD \\
\hline $\begin{array}{l}\text { 9. I certainly feel } \\
\text { useless at times. }\end{array}$ & SA & A & D & SD \\
\hline $\begin{array}{l}\text { 10. At times I } \\
\text { think I am no good } \\
\text { at all. }\end{array}$ & SA & A & $\mathrm{D}$ & SD \\
\hline
\end{tabular}




\begin{abstract}
Appendix C
NOW

ROSENBERG SELF-ESTEEM SCALE (RSES)
\end{abstract}

BELOW IS A LIST OF STATEMENTS DEALING WITH YOUR GENERAL FEELINGS ABOUT YOURSELF. IF YOU STRONGLY AGREE, CIRCLE SA. IF

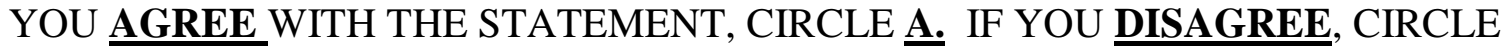
D. IF YOU STRONGLY DISAGREE, CIRCLE $\underline{\text { SD. }}$

\title{
PLEASE ANSWER THE QUESTIONS ACCORDING TO HOW YOU
} CURRENTLY FEEL AT THIS TIME!!!

\begin{tabular}{|l|c|c|c|c|}
\hline & $\begin{array}{l}\text { 1. } \\
\text { STRONGLY } \\
\text { AGREE }\end{array}$ & AGREE & DISAGREE & $\begin{array}{l}\text { 4. } \\
\text { STRONGLY } \\
\text { DISAGREE }\end{array}$ \\
\hline $\begin{array}{l}\text { 1. I feel that I'm a } \\
\text { person of worth, at } \\
\text { least on an equal } \\
\text { plane with others. }\end{array}$ & SA & A & D & SD \\
\hline $\begin{array}{l}\text { 2. I feel that I have } \\
\text { a number of good } \\
\text { qualities. }\end{array}$ & SA & A & D & SD \\
\hline $\begin{array}{l}\text { 3. All in all, I am } \\
\text { inclined to feel that } \\
\text { I am a failure. }\end{array}$ & SA & A & D & SD \\
\hline $\begin{array}{l}\text { 4. I am able to do } \\
\text { things as well as } \\
\text { most other people. }\end{array}$ & SA & A & D & SD \\
\hline $\begin{array}{l}\text { 5. I feel I do not } \\
\text { have much to be } \\
\text { proud of. }\end{array}$ & SA & A & D & SD \\
\hline $\begin{array}{l}\text { 6. I take a positive } \\
\text { attitude toward } \\
\text { myself. }\end{array}$ & SA & A & D & SD \\
\hline $\begin{array}{l}\text { 7. On the whole, I } \\
\text { am satisfied with } \\
\text { myself. }\end{array}$ & SA & A & D & SD \\
\hline $\begin{array}{l}\text { 8. I wish I could } \\
\text { have more respect } \\
\text { for myself. }\end{array}$ & SA & A & D & SD \\
\hline $\begin{array}{l}\text { 9. I certainly feel } \\
\text { useless at times. }\end{array}$ & SA & A & D & SD \\
\hline $\begin{array}{l}\text { 10. At times I } \\
\text { think I am no good } \\
\text { at all. }\end{array}$ & SA & A & D & SD \\
\hline
\end{tabular}




\section{Appendix D}

\section{PLEASE ANSWER THE FOLLOWING QUESTIONS} AS ACCURATELY AS POSSIBLE.

1. Please indicate your total cumulative grade point average to date (e.g. 2.67):

2. Please indicate your total number of completed credit hours to date (not including the current semester):

3. Please indicate your major:

4. Please circle your gender: male female. 


\section{JENNIFER L. WILES}

2157 University Ave. Apt. \# 1

Morgantown, WV 26505.

Tel: (304)-292-4036

Email: jwiles@hsc.wvu.edu

\section{EDUCATION}

01/2004-Present

Doctoral student, Department of Educational Psychology, West Virginia University Major: Educational Psychology Cumulative GPA: 4.0

08/2002 - 05/2004

Master's student, Department of Educational Psychology, West Virginia University

Major: Educational Psychology Cumulative GPA: 4.0

08/1998 - 05/2002

Bachelor of Arts in Psychology, West Virginia University

Major: Psychology Minor: Communications Cumulative GPA: 3.6

\section{WORK EXPERIENCE}

08/2002 - Present

Graduate Research Fellow at the Prevention Research Center, West Virginia University

Responsibilities include data collection, data entry (SPSS), analyses of data, and evaluation oversight. Other responsibilities include conducting literature reviews, and assisting with article preparation, publication, and presentations.

05/2000 - Present

\section{Residential Program Advisor}

Responsibilities include the designing of programs to teach disabled persons daily performance tasks, including community integration, and the oversight of implementation of such programs.

04/2004 - Present

Mobile Therapist

Responsibilities include assisting with counseling children/adolescents and writing goals to fit their daily needs. Other responsibilities include conducting intense sessions with family members and/or teachers to fulfill needs and assess all areas of the client's life.

\section{RESEARCH EXPERIENCE}

01/2002-05/2002

\section{Psychology Research Assistant}

Responsibilities included recruitment of participants, data entry, and data analysis of the research topic while assisting with other relevant duties pertaining to the selected graduate student's dissertation. 


\section{TEACHING EXPERIENCE}

01/2002 - 05/2002

Psychology Teaching Assistant

Responsibilities included guest lecturing, objective grading of colleagues, assisting with the preparation of lecture materials, and performing meaningful lab lectures to aid the lecture material.

\section{HONORS/AFFILIATIONS:}

Member of Gamma Beta Phi, Honors Fraternity

Member of Psi Chi, Psychology Honor Society

Member of Golden Key International Honor Society

Member of Psychology Club

Recipient of Dean's List (1998 -2002)

Recipient of Eberly College of Arts \& Sciences Scholarship

Recipient of Robert C. Byrd Health Sciences Scholarship

Recipient of Stephanie Santello Scholarship (Berkeley Medical)

\section{REFERENCES}

Available upon request 